\title{
Relationship between crack length, wedge-shaped cutter geometry, and salt rocks viscosity in a cross-cutting scheme
}

\author{
Nelli A. Kharlamova ${ }^{1 *}$, Mariia A. Konovalova ${ }^{1}$ \\ ${ }^{1}$ Perm National Research Polytechnic University, Perm, Russia \\ *e-mail: nellia59@yandex.ru
}

\begin{abstract}
Introduction. Existing publications lack studies on the relationship between salt rocks physical properties, cutters geometry, cutting force, and intergranular fracture of rock under the cutter. By analyzing the system of cracks formed by the cutters between the cutting lines, it is possible to estimate the efficiency of fracture and design the nature and conditions of cutting.

Research aim is to obtain an analytical dependence that links cracks size, cutter geometry, and salt rocks crack resistance; calculate the cutting force; experimentally determine sylvine, halite and carnallite fracture toughness coefficients necessary for the calculation. And finally, based on the obtained data, the research aimed to build $3 D$ graphs of crack length dependence on cutter geometry for a cross-cutting scheme.

Methodology. Sylvine, halite and carnallite crack resistance coefficients were obtained by indentation. The coefficient values were used in the formula for calculating the size of cracks between the cutting lines in these rocks. The formula was corrected after D6.22 cutter indentation test in salt rocks. Light microscopy technique was used to study fluid inclusions in salt rocks.

Results. Analytical dependence, values of crack resistance coefficients were obtained. $3 D$ graphs for halite, sylvine and carnallite were constructed for the cross-cutting scheme. The type, size and concentration of fluid inclusions along the grain boundaries are given that accelerate intergranular fracture under the cutter.

Conclusions. The resulting formula relates cutter geometry (cutting rim width and cutting angle) to the cutting force and viscosity of rocks. The formula was used to build the $3 D$ graphs for sylvine, halite and carnallite for the cross-cutting scheme. The size of cracks under the cutter is connected with the presence of fluid inclusions. The obtained analytical dependence allows to model the spatial distribution and size of microfractures in salt rocks under the action of the cutting tool. Excessive branching of cracks, energy intensity, and the number of small fractions decrease, when the trajectory of the cutter partially passes through the "technogenic" cracks of the previous bed. This is implemented in the cross-cutting scheme, where this group of cracks plays the role of "starting" ones. Their length in actual practice is important for justifying the optimal cutting parameters and estimating the cutter's efficiency.
\end{abstract}

Key words: indentation; fracture toughness; salt rock; fluid (gas-liquid) inclusions; cutter; cracks; graphs; cross-cutting scheme.

Introduction. Mechanical rock breaking is the main method of mining potassiummagnesium ore in the majority of fields. Efficient breaking methods haven't been sufficiently developed and physically substantiated. Existing researches consider the process phenomenologically and do not reveal its internal mechanism. In this regard, there are some problems in substantiating rational parameters of cutting. It is impossible to design the cutting process without the integrated estimation of rock properties and cutter geometry as well as without some knowledge in the nature of the process.

Starkov L. I. proposed the cross-cutting scheme and the corresponding structure of the cutter tools. The main point of the scheme is that the cutting process consists of the 
two phases. In the first phase, the cutters move along the preset trajectories in the same direction, while in the second phase they move at a right angle to the cutters' motion in the first phase. The scheme was named as the cross-cutting scheme (CCS). The researches have shown the efficiency of this cutting scheme [1,2]: outsized fraction and power intensity reduction.

The connection between the cutters geometry, rock viscosity (crack resistance), cutting force and intergranular fractures under the cutter were discussed in works [3, 4].

The effect of the cutters geometry on the operating parameters of the operating devices, cutting force, energy intensity, and cutters durability were analyzed in works [5-9]. There've been found no researches which would have resulted in creating a dependence graph or analytical dependence connecting salt rock viscosity, cutters geometry, cutting force, and intergranular fracture under the cutter for a cross-cutting scheme.
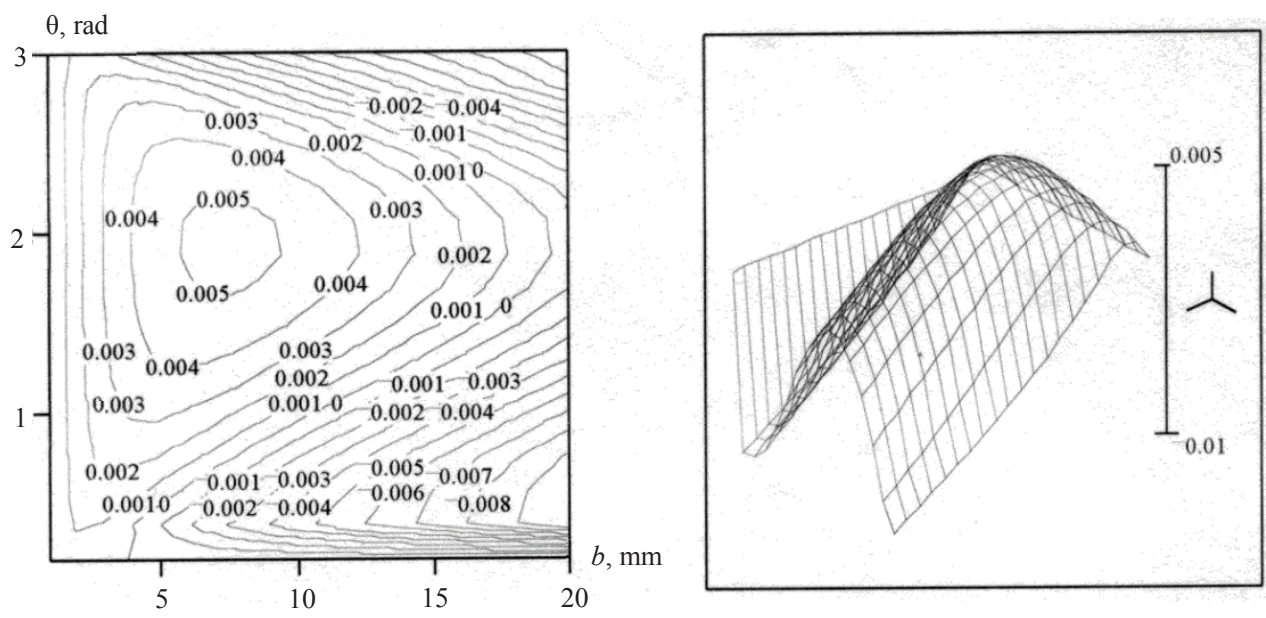

Fig. 1. Dependence of the crack length $C_{s}$ between the cutting lines on the cutting $\operatorname{rim} b$ and the edge angle $\theta$ in sylvine

Рис. 1. Зависимость длины трещин $C_{s}$ между линиями резов от ширины режущей кромки $b$ и угла заострения $\theta$ в сильвине

Research aim was to obtain the analytical dependence between cracks length under the cutters and salt rock viscosity, cutter geometry and cutting force. In order to get that done, the research aimed to measure crack resistance (viscosity) of sylvine, halite and carnallite. Based on the obtained dependence, the research aimed to build 3D graphs for a cross-cutting scheme, explain the distinctive features of the dependence graphs, and reveal the appearance and size of fluid inclusions of salt rocks which significantly influence the character of the obtained dependence graphs.

Methodology. In order to reveal the dependence of cracks length on salt rocks viscosity, cutter's geometry, and cutting force, the method of indentation has been selected. Indentation determines crack resistance in accordance with the analytic expression connecting fracture toughness and the size of load on the indenter, indenter geometry, and cracks size. The action of the indenter is like the action of the cutter. In works $[3,10]$ the method of determining the fracture toughness (crack resistance) by indentation was described: the pyramid-shaped indenter (Vickers indenter) is impressed into the polished surface of the sample. Among the existing methods of determining fracture toughness, indentation is perhaps the only one allowing to compare crack growth resistance in a set of salt rock structural differences. Tests were performed at PMT-3 and TP-7r-1 devices using the Vickers indenter under various loads. 
Indentation was used together with some extra tests on pressing D6.22 cutter cap, as an indenter, into the salt rock under fixed load. Indentation was performed at Rockwell testing machine under the loads of 60, 100 and $150 \mathrm{kgf}$.

Cutters of various types (for example, wedge-shaped cutters D6.22 and cylindrical cutters RKS) create a particular system of cracks at the surface of the conditioned matter. Tangential cutter has a polarized effect of breaking (like the indenter) and is preferable as soon as the breaking efficiency is concerned. For that reason, the research was made using tangential cutters. Cracks around the depression from the tangential cutter may be split into two groups: fine cracks network under the depression and cracks which fan out from the depression edges and remain in the ridges between the cutting lines. The second group is crucial in CCS. Let us call them "technogenic". In the rock blocks broken by the cutter like in laboratory samples there are radial fractures propagating from the edges of the depression. It is not always possible to determine the size of these fractures. However, these fractures, specifically directed relative to the following cuts, make the breaking of the following layer easier.
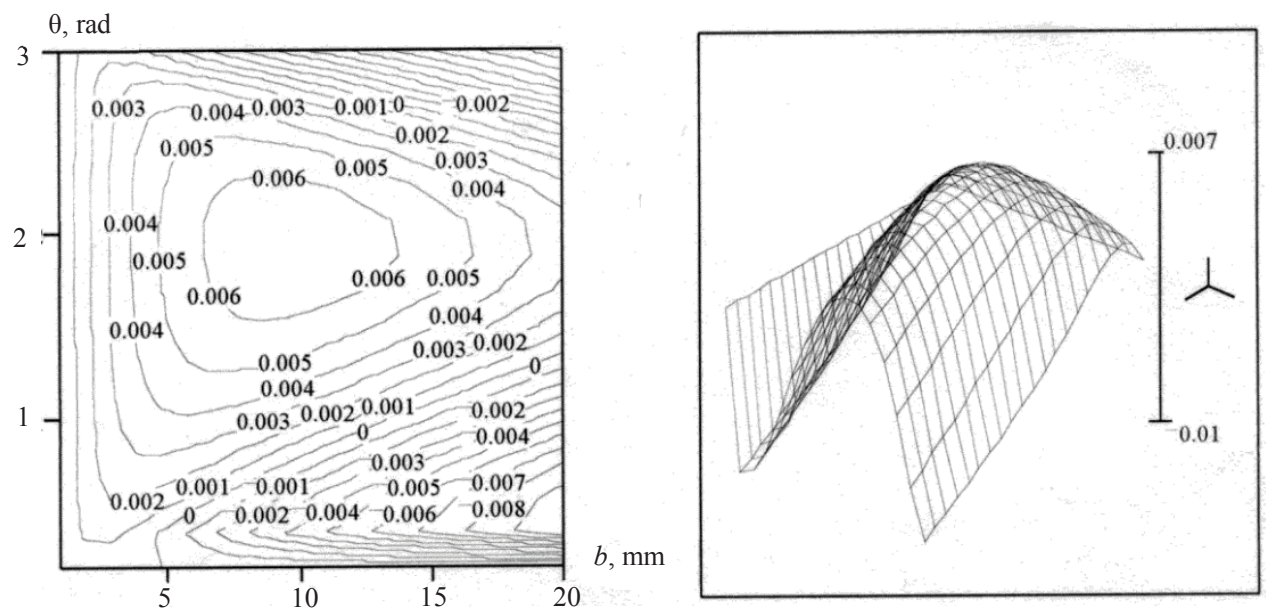

Fig. 2. Dependence of the crack length $C_{r}$ between the cutting lines on the cutting $\operatorname{rim} b$ and the edge angle $\theta$ in halite

Рис. 2. Зависимость длины трещин $C_{r}$ между линиями резов от ширины режущей кромки $b$ и угла заострения $\theta$ в галите

Observation, measurements and photographs of the fluid inclusions, which have a significant impact on the distribution and size of fractures, were carried out at the binocular microscope MBS-9 under the magnifications of 7, 30, and 60 .

Results. Test samples were selected from the lower sodium chloride, sylvinite, and carnallite of the Upper Kama potash salt deposit. For the tests, the samples with various grain size and colour were selected. The crack resistance coefficient (fracture toughness), $K_{1 c}$, was determined from the formula:

$$
K_{1 c}=\frac{2.3 \sin \theta P}{\mathrm{~F}(a)^{3 / 2}} \lg \frac{4.5 a}{C_{r}}
$$

where $\theta$ is the angle between the direction of the surface and the face of the indenter; $P$ is the load on the indenter; $2 a$ is the length of the depression diagonal; $C_{r}$ is a half of the crack's length; $\mathrm{F}$ is a constant, $\mathrm{F} \approx 3$ for the majority of materials.

Mean values obtained by the method of indentation for sylvine, halite and carnallite are $3.5,1.3$ and $0.27 \mathrm{MPa} \cdot \mathrm{m}^{1 / 2}$ correspondingly. 
In order to make the results of dimensioning the cracks between the cutting lines from cutters meet their values obtained by indentation, the experiment on pressing D6.22 cutter cap, as an indenter, into the salt rock at fixed load was carried out. Indenter depression length and the length of the cracks fanning out from the depression edges were measured. After measuring the length of the cracks fanning out from the angles of the cutter's rim depression and the length of the depression itself, the value of the $\mathrm{FK}_{1 c}$ product was determined from the formula

$$
\mathrm{F} K_{1 c}=\frac{2.3 \sin \theta P}{(b / 2)^{3 / 2}} \lg \frac{4.5 b / 2}{C_{r}}
$$

where $b$ is the width of the cutting rim. The mean values of $4.6,3.6$ and $1 \mathrm{MN} \cdot \mathrm{m}^{-3 / 2}$ were obtained for sylvine, halite and carnallite correspondingly.
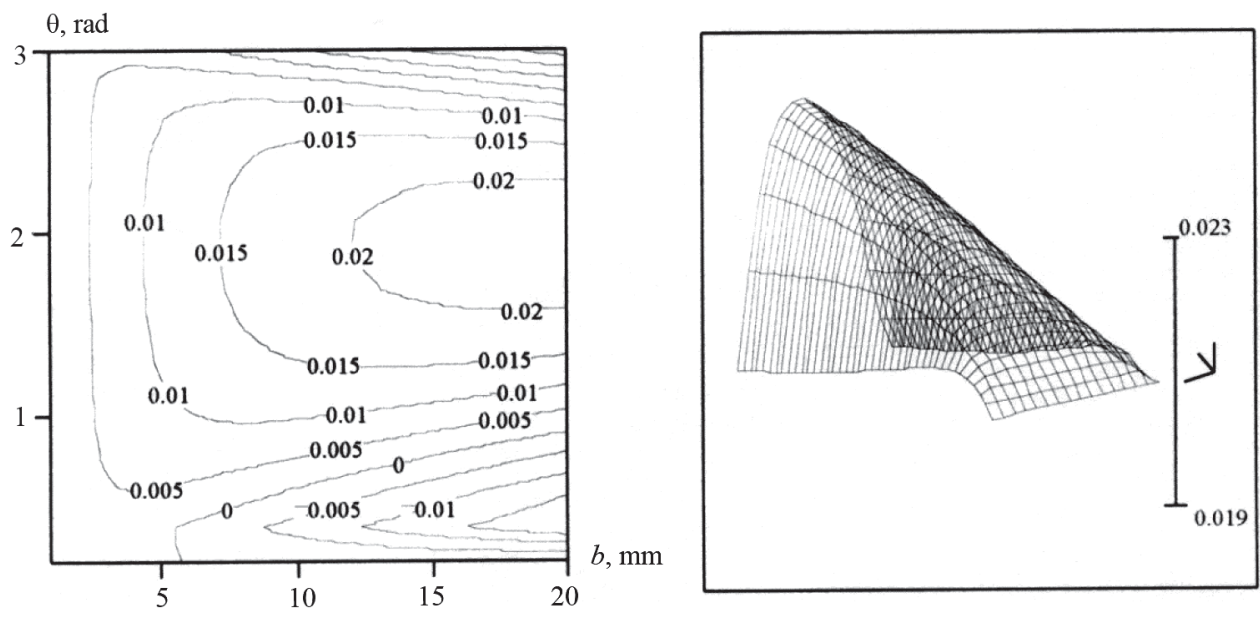

Fig. 3. Dependence of the crack length $C_{k}$ between the cutting lines on the cutting $\operatorname{rim} b$ and the edge angle $\theta$ in carnallite

Рис. 3. Зависимость длины трещин $C_{k}$ между линиями резов от ширины режущей кромки $b$ и угла заострения $\theta$ в карналлите

After that, crack length back-calculation should be done for actual cutting using the obtained values of $\mathrm{FK}_{1 c}$. It was determined beforehand whether the load intensity coefficient $K_{1 c}$ depends on the speed of the cutter (indenter). It was proved in research [11] that the value of the load intensity coefficient doesn't depend on the speed of the indenter within the range of $0.005-10 \mathrm{~mm} / \mathrm{min}$. Work [3] carried out extra experiment on the dynamic impact of the wedge-shape cutter on the salt rock. According to the results of the experiment, an order of magnitude of FK1c remained the same while the numerical value was within the range of this value in the obtained set of measurements.

Calculation of the dependence between the cutting force, cutting rim width, and the edge angle was done in two ways. In the first variant the force, kgf, calculated by the formula recommended in work [12] was introduced in crack size calculation:

$$
Z=A_{c} h_{\mathrm{mdl}}^{n} K_{b} K_{a} K_{(t-b) / h}
$$

where $K_{b}=0.3+0.35 b_{k} ; K_{a}=0.55+0.009 \alpha_{p}$; in the calculation the cutting angle $\alpha$ was substituted for angle $\theta+0.2 \theta$, where $\theta$ is the edge angle; $A_{c}$ is the cutting resistance 
equal to the force falling on $1 \mathrm{~cm}$ of the cutting depth. Cutting resistance was taken equal to $3000 \mathrm{~N}$ (from bench test result); $h=1 \mathrm{~cm}, K_{(t-b) / h}=0.7$ (for the width of $1 \mathrm{~cm}$ and mean values of $b=10 \mathrm{~mm}, t=30 \mathrm{~mm}$ ).

Table 1. Parameters of fluid inclusions between the grains for some structural differences of salt rock

Таблица 1. Параметры флюидных включений, локализованных между зернами, для некоторых структурных разностей соляных пород

\begin{tabular}{l|c|c|c|c}
\hline \multicolumn{1}{c|}{ Rock, colour } & $\begin{array}{c}\text { Maximum size, } \\
\mu \mathrm{m}\end{array}$ & $\begin{array}{c}\text { Most probable } \\
\text { size, } \mu \mathrm{m}\end{array}$ & $\begin{array}{c}\text { Transverse size, } \\
\mu \mathrm{m}\end{array}$ & $\begin{array}{c}\text { The fraction of the grain } \\
\text { boundary area, occupied } \\
\text { by the inclusions, } \%\end{array}$ \\
\hline Rock salt, light grey & $150 \times 140$ & $140 \times 140$ & $1-3$ & $10-50$ \\
Rock salt, dark grey & $40 \times 30$ & $\begin{array}{c}40 \times 30 \\
4 \times 4\end{array}$ & 1 & $0-35$ \\
White sylvine & $40 \times 30$ & $\begin{array}{c}15 \times 15 \\
5 \times 5\end{array}$ & - & $1 \times 10$ \\
Pink sylvine & $50 \times 50$ & $2 \times 2$ & - & $1 \times 5$ \\
Carnallite & $1400 \times 420$ & $420 \times 30$ & $15 \times 150$ & $30-50$ \\
& $700 \times 280$ & & &
\end{tabular}

The obtained formula for back-calculation of the crack length:

$$
c_{i j}=\frac{4.5 \cdot 0.5 b_{i}}{10^{r_{i j}}}-0.5 b_{i}, \quad \text { where } \quad r_{i j}=\frac{\left(0.5 b_{i}\right)^{3 / 2} \mathrm{~F} K_{1 c}}{Z \cdot 2.3 \sin \theta_{j}}
$$

Calculation of dependence between crack length, wedge-shaped cutter geometry, and the viscosity of salt rock was done for the cross-cutting scheme. The calculation is presented in fig. 1, 2, 3 for sylvine, halite and carnallite as graphs. In the 3D graphs, the sizes of cracks are presented which develop when working with the wedge-shaped cutters with various cutting rim width and edge angles.

In the cross-cutting scheme the swarf is separated partially along the cracks left in the ridges (ribs) between the cutting lines of the previous bed. These cracks are larger when using the cross-cutting scheme as compared to sequential cutting scheme and the checkerboard cutting scheme [4]. Optimal cutters parameters for CCS turned out to be wider.

Negative values on the graph mean that the crack under the cutter does not go beyond the cutter's rim and does not propagate into the ridge between the cutting lines. Cutters with geometric parameters to the right of the zero contour are ineffective. All tests and calculations were made for a single sharp standard cutter.

In the second variant the dependence between the force, width, and the edge angle for the depth of $h=5 \mathrm{~mm}$ was calculated from the expression

$$
Z=28 \cdot 10^{4} b \operatorname{tg}(\theta / 2)
$$

where $28 \cdot 10^{4}, \mathrm{~N} / \mathrm{m}^{2}$, is the pressure from the salt rock on a unit of the cutter's crosssection. In graphs similar to fig. 1, 2, 3, the optimum size square of the cutter increases. For sylvine and halite the size of cracks is $2-3$ times larger in CCS as compared to the conventional cutting schemes.

A significant distinction of the dependence graph for carnallite as compared to the same dependences for halite and silvine can basically be explained by the following. Halite and sylvine have similar crystal structure, which is a cubic crystal system. 
The crystal lattice is ionic; perfect cleavage in three directions along the cube faces. Carnallite is a mineral from halide class, magnesium chloride and potassium chloride double salt. Rare in crystals, they are pseudohexagonal and frequently swollen because of strong hygroscopy. No cleavage, uneven fracture, entire grainy masses, easily spreading in humid air.
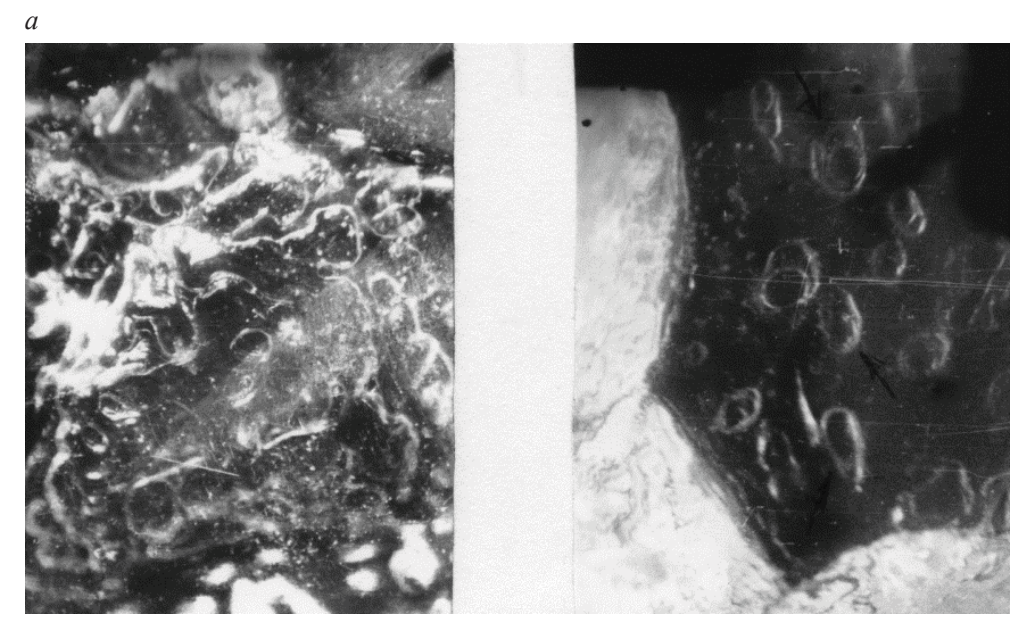

$b$
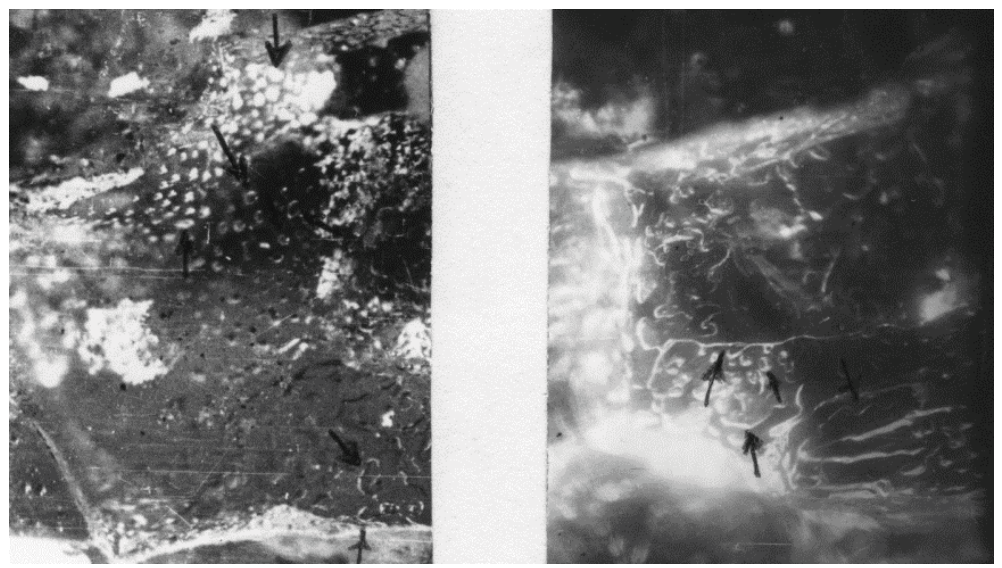

Fig. 4. Gas-liquid fluid inclusions localized along the grain boundaries: $a-$ in carnallite; $b$ - in grey rock salt

Рис. 4. Газово-жидкие флюидные включения, локализованные по границам зерен:

$a-$ в карналлите; $b-$ в серой каменной соли

Furthermore, the structural element reducing rock resistance against crack growth are the fluid inclusions. They are localized in halite, sylvine and carnalite most commonly along the grain edges and are the crack-like cavities having a form of disks, lentils, and more complex forms and are conditioned by the saline deposits genesis. According to the theory of gas origin at the Upper Kama potash salt deposit by Iu. V. Morachevskii and A. A. Cherepennikov, gas development is connected with the decay of animal and green residue. In work [3] the connection between the start of disintegration and the presence of discontinuities and fracture origins in grain edges was proven quantitatively.

The size of these inclusions, their concentration and the fraction of the area of the total area of grain edges are presented in table 1 . The measurements were carried out 
for a set of structural differences of rock salt and carnallite with typical size, shape and fluid inclusions distribution (fig. 4). Sixty samples of rock salt and sylvinite representing a set of structural differences, and forty samples of carnalite were investigated.

Summary. By means of reducing the excessive branching of cracks, the energy intensity and friction reduction becomes possible, when the trajectory of the cutter partially passes through the "technogenic" cracks of the previous bed. This is implemented in the cross-cutting scheme, where this group of cracks plays the role of "starting" ones. Their length in real conditions is important for justifying the optimal cutting parameters and estimating the cutter's efficiency.

In future, in order to determine the optimal depth, pace and scheme of cutting, the spatial distribution can be simulated together with the parameters of salt rock intergranular fracture as a result of the cutting tool's impact. In the end, it impacts the output of fine fractions and the cutting force. The obtained dependence connects the fracture toughness of the salt rock, cutting force and geometry of the cutter. Specifying and correcting it, it is possible to predict the effectiveness of particular cutters for particular forces, modes and cutting schemes.

\section{REFERENCES}

1. Starkov L. I., Kharlamova N. A. Studying the cross-cutting scheme. Izvestiya vysshikh uchebnykh zavedenii. Gornyi zhurnal $=$ News of the Higher Institutions. Mining Journal. 1997; 7-8: 121-123. (In Russ.)

2. Shishliannikov D. I. Enhancement of the bodies of destruction of heading-and-winning machines of the "Ural" type. Izvestiia Uralskogo gosudarstvennogo gornogo universiteta = News of the Ural State Mining University. 2017; 2(46): 71-74. (In Russ.)

3. Kharlamova N. A. Studying the mechanism of rock breaking by a cutting tool: PhD in Engineering diss. Perm: 1998: 110-112. (In Russ.)

4. Kharlamova N. A., Konovalova M. A. Dependence of fracture length on wedge cutter bit geometry and viscosity of salt rocks. Gornyi informatsionno-analiticheskii biulleten (nauchno-tekhnicheskii zhurnal) = Mining Informational and Analytical Bulletin (scientific and technical journal). 2018; 4: $204-209$. (In Russ.)

5. Semenov V. V., Shmakin I. G., Zhabin A. B., Surov I. A. Justification of parameters and selection of cutters of the executive body of "Ural-61" tunneling machine for potassium ore mining. Gornoe oborudovanie i elektromekhanika = Mining Equipment and Electromechanics. 2010; 4: 6-9. (In Russ.)

6. Neskromnykh V. V., Borisov K. I. Analytical study of cutting and shearing action of PDC bits. Izvestiia Tomskogo politekhnicheskogo universiteta = Bulletin of the Tomsk Polytechnic University. 2013; 323(1): 191-192. (In Russ.)

7. Pavlysh V. N., Steblin V. V., Topchii S. E., Grodzinskii P. Ia. Investigation of characters of cutting tools of executive elements of modern mining machines. Progresivni tekhnologii $i$ sistemi mashinobuduvannia = Advanced Technologies and Mechanical Engineering. 2014; 2(48): 15-21.

8. K. Pradeep Kumar Mouli1, Srinivasa Rao Nandam, P. Vijay Kumar Raju, G. Appala Raju, A. Chandrakanth. Optimization of cutting tool geometry by CAE approach for titanium alloy. In: $1 P$ 5th International \& 26th All India Manufacturing Technology, Design and Research Conference (AIMTDR 2014) December 12th-14th, 2014, IIT Guwahati, Assam, India. P. 667-1, 667-6.

9. Zhang Qianqian, Han Zhennan, Zhang Mengqi, Zhang Jianguang. Prediction of tool forces in rock cutting using discrete element method. 1 College of Mechanical Engineering, Taiyuan University of Technology, Taiyuan Shanxi 030024, China 2 Taiyuan Institute of China Coal Technology and Engineering Group, Taiyuan 030006, China 2015. P. 1607-1725.

10. Tiurin A. I., Shuvarin I. A., Pirozhkova T. S., Kupriashkin A. M. Influence size effect and type indenter on criteria correct definition of fracture toughness at dynamic microand nano-indentation. Vestnik $T G U=$ Tambov University Reports. Series Natural and Technical Sciences. 2013; 18(4): 1593-1594.

11. Zilbershmidt V. G., Titov B. V. Dependence between the viscosity of salt rock and the speed of deformation. Izvestiya vysshikh uchebnykh zavedenii. Gornyi zhurnal = News of the Higher Institutions. Mining Journal. 1987; 8: 5-7.

12. Brenner V. A., Zhabin A. B., Shchegolevskii M. M. Shield tunneling systems. Moscow: Gornaia kniga Publishing; 2009. (In Russ.)

Received 6 July 2020

\section{Information about authors:}

Nelli A. Kharlamova - PhD (Engineering), Associate professor of the Department of General Physics, Perm National Research Polytechnic University. E-mail: nellia59@yandex.ru

Mariia A. Konovalova - senior lecturer, Department of General Physics, Perm National Research Polytechnic University. E-mail: mashkin__mail.ru 


\title{
Зависимость длины трещин от геометрических параметров клинового резца и вязкости соляных пород для перекрестной схемы резания
}

Харламова Н. А. ${ }^{1}$, Коновалова М. А. ${ }^{1}$

${ }^{1}$ Пермский национальный исследовательский политехнический университет, Пермь, Россия.

\begin{abstract}
Peфepam
Введение. Обзор существующих публикаций показывает, что в них отсутствуют исследования взаимосвязи физических свойств соляных пород, геометрии резцов, силь резания имикроразрушений пород под резцом. Анализируя систему трещин, образованных резцами между линиями резов, можно оценить эффективность разрушения и спроектировать характер и условия резания.

Цель работы. Получить аналитическую зависимость, связывающую размер трещин с геометрическими параметрами резца и трещиностойкостью соляных пород. Учесть усилие резания. Экспериментально определить необходимые для расчета коэффициенты вязкости разрушения для сильвина, галита и карналлита. На основании полученных данных построить 3D-графики зависимости длины трещчин от геометрических параметров резца для перекрестной схемь резания.

Методология. Методом индентирования получень коэффициенты трещиностойкости для сильвина, галита и карналлита. Значения коэффициентов использованы в формуле для расчета размеров трещчин между линиями резов в этих типах горных пород. Формула скорректирована после испытаний по вдавливанию резца D6.22 в соляные породы. Использовали метод оптической микроскопии для изучения флюидных включений в соляных породах.

Результаты. Получены аналитическаязависимость, значения коэффищиентовтрещииностойкости, построены 3D-графики для галита, сильвина и карналлита для перекрестной схемь резания. Приведены вид, размеры и концентрация флюидных включений, локализованных по границам зерен, ускоряющих микроразрушения под резцом.

Выводы. Полученная формула связывает геометрию резиа (иирину режущей кромки и угол

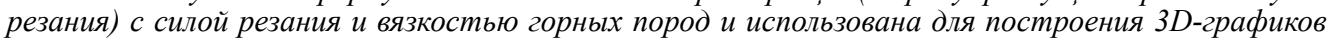
для сильвина, галита и карналлита для схемы перекрестного резания. Величина трещци под резцом связана с наличием флюидных включений. Полученная аналитическая зависимость позволяет моделировать пространственное распределение и размеры микротрещчин в соляных породах под действием режущего инструмента. Когда траектория резиа частично проходит по «техногенным» трещинам отработанного слоя, уменьшаются избыточное ветвление трещин, энергоемкость, количество мелких фракиий. Это реализуется в схеме перекрестного резания, где эта группа трещин играет роль «стартовых». Их длина в реальных условиях имеет значение для обоснования оптимальных параметров резания и оценки эффективности работы резца.
\end{abstract}

Ключевые слова: метод индентирования; вязкость разрушения; соляные породы; флюиднье (газово-жидкие) включения; резеи; трещины; графики; перекрестная схема резания.

\section{БИБЛИОГРАФИЧЕСКИЙ СПИСОК}

1. Старков Л. И., Харламова Н. А. Исследование схемы перекрестного резания // Известия вузов. Горный журнал. 1997. № 7-8. С. 121-123.

2. Шишлянников Д. И. Совершенствование органов разрушения проходческо-очистных комбайнов типа «Урал»// Известия Уральского государственного горного университета. 2017. Вып. 2(46). С. 71-74.

3. Харламова Н. А. Исследование механизма разрушения горных пород резцовым инструментом: дис. ... канд. техн. наук. Пермь, 1998. С. 110-112.

4. Харламова Н. А., Коновалова М. А. Зависимость длины трещин от геометрических параметров клинового резца и вязкости соляных пород // ГИАБ. 2018. № 4. С. 204-209.

5. Семенов В. В., Шмакин И. Г., Жабин А. Б., Суров И. А. Обоснование параметров и выбор резцов исполнительного органа проходческо-очистного комбайна для добычи калийных руд // Горное оборудование и электромеханика. 2010. № 4. С. 6-9.

6. Нескромных В. В., Борисов К. И. Аналитическое исследование процесса резания-скалывания горной породы долотом с резцами РDC // Известия Томского политехнического университета. 2013. T. 323. № 1. С. 191-192.

7. Павлыш В. Н., Стеблин В. В., Топчий С. Е., Гродзинский П. Я. Исследование характеристик режущих инструментов исполнительных органов современных горных машин // Прогресивні технології і системи машинобудування. 2014. № 2(48). С. 15-21.

8. K. Pradeep Kumar Mouli1, Srinivasa Rao Nandam, P. Vijay Kumar Raju, G. Appala Raju, A. Chandrakanth. Optimization of cutting tool geometry by CAE approach for titanium alloy // 1P 5th International \& 26th All India Manufacturing Technology, Design and Research Conference (AIMTDR 2014) December 12th-14th, 2014, IIT Guwahati, Assam, India. P. 667-1, 667-6.

9. Zhang Qianqian, Han Zhennan, Zhang Mengqi, Zhang Jianguang. Prediction of tool forces in rock cutting using discrete element method. 1 College of Mechanical Engineering, Taiyuan University of 
Technology, Taiyuan Shanxi 030024, China 2 Taiyuan Institute of China Coal Technology and Engineering Group, Taiyuan 030006, China 2015. P. 1607-1725.

10. Тюрин А. И., Шуварин И. А., Пирожкова Т. С., Купряшкин А. М. Влияние масштабного фактора и типа индентора на критерии корректного определения вязкости разрушения при динамическом микро- и наноиндентировании // Вестник ТГУ. 2013. Т. 18. Вып. 4. С. 1593-1594.

11. Зильбершмидт В. Г., Титов Б. В. Зависимость вязкости разрушения каменной соли от скорости деформирования // Известия вузов. Горный журнал. 1987. № 8. С. 5-7.

12. Бреннер В. А., Жабин А. Б., Щеголевский М. М. Щитовые проходческие комплексы. М.: Горная книга, 2009. 449 с.

Поступила в редакцию 6 июля 2020 года

\section{Сведения об авторах:}

Харламова Нэлли Артемьевна - кандидат технических наук, доцент кафедры общей физики Пермского национального исследовательского политехнического университета. E-mail: nellia59@yandex.ru

Коновалова Мария Алексеевна - старший преподаватель кафедры общей физики Пермского национального исследовательского политехнического университета. E-mail: mashkin__@mail.ru

Для цитирования: Харламова Н. А., Коновалова М. А. Зависимость длины трещин от геометрических параметров клинового резца и вязкости соляных пород для перекрестной схемы резания // Известия вузов. Горный журнал. 2020. № 8. C. 26-34 (In Eng.). DOI: 10.21440/0536-10282020-8-26-34

For citation: Kharlamova N. A., Konovalova M. A. Relationship between crack length, wedge-shaped cutter geometry, and salt rocks viscosity in a cross-cutting scheme. Izvestiya vysshikh uchebnykh zavedenii. Gornyi zhurnal $=$ News of the Higher Institutions. Mining Journal. 2020; 8: 26-34. DOI: $10.21440 / 0536-1028-2020-8-26-34$ 